\title{
Deneysel Ölçüme Dayalı Beslenme Eğitiminin Ortaokul Öğrencilerinin Beslenme Davranışlarına ve Beslenme Öz-Yeterliklerine Etkisinin İncelenmesi*
}

\section{Investigation on the Effectiveness of Experimental Measurement Based Nutrition Training on the Nutritional Behavior and Nutrition Proficiency of Secondary School Students}

\author{
Mustafa Özgenel $^{\mathrm{a}^{* *}}$, Ferah Özden $^{\mathrm{b}}$ \\ a Dr. Öğretim Üyesi, İstanbul Sabahattin Zaim Üniversitesi, Eğitim Fakültesi, 34662, İstanbul/Türkiye. \\ ORCID: 0000-0002-7276-4865 \\ ${ }^{\mathrm{b}}$ Fen Bilimleri Öğretmeni, Milli Eğitim Bakanlığı, 34303, İstanbul/Türkiye. \\ ORCID: 0000-0002-9589-9236
}

\begin{tabular}{l} 
MAKALE BİLGİSI \\
\hline Makale Geçmişi: \\
Başvuru tarihi: 21 Ekim 2018 \\
Düzeltme tarihi: 18 Kasım 2018 \\
Kabul tarihi: 14 Artalık 2018 \\
\end{tabular}

\section{Anahtar Kelimeler:}

Beslenme,

Beslenme Davranış1,

Beslenme Eğitimi,

Beslenme Öz-yeterlik,

Deneysel Desen

\section{ARTICLE INFO}

\section{Article history:}

Received: 21 October 2018

Received in revised form: 18 November 2018 Accepted : 14 December 2018

\section{Keywords:}

Nutrition,

Nutrition Behavior,

Nutrition Education,

Nutrition Self-efficacy,

Experimental Design
ÖZ

Bu çalışmanın amacı, deneysel ölçüme dayalı beslenme eğitiminin, ortaokul öğrencilerinin beslenme davranışlarına ve beslenme öz-yeterliklerine etkisini araştırmaktır. Araştırmada, kontrol gruplu ön test-son test deneysel desen kullanılmıştır. Araştırma, 2017-2018 öğretim yılında, 38 gönüllü öğrenci ile yürütülmüştür. Veriler, Çocuk Beslenme Öz-Yeterlik Ölçeği ve Beslenme Davranış Ölçeği ile toplanmıştır. Veriler bağımsız gruplar t testi yapılarak analiz edilmiştir. Bulgulara göre deney ve kontrol grubundaki öğrencilerin beslenme davranışları ön test ve son test fark puanları deney grubu lehine anlamlı farklılık gösterirken, beslenme öz-yeterlik ön test ve son test fark puanları anlamlı bir farklılık göstermemektedir. Ancak, deney grubundaki öğrencilerin beslenme öz yeterlik ortalama puanları, kontrol grubundaki öğrencilerin ortalama puanlarından daha yüksektir. Bu sonuçlara göre belirli bir program dâhilinde öğrencilere beslenme eğitimleri verilmesi önerilebilir.

\section{A B S T R AC T}

The aim of this study is to investigate the effect of experimental measurement based nutrition education on nutrition behaviors and nutrition self-sufficiency of middle school students. In the study, pretest- posttest experimental pattern with control group was used. The research was carried out with 38 volunteer students in the 2017-2018 academic year. The data were collected with The Child Nutrition Self-Efficacy Scale and Nutrition Behavior Scale. The data were analyzed by independent groups $t$ test. According to the findings, the pre-test and post-test difference scores of students nutritional behaviors in the experimental and control groups differed significantly in favor of the experimental group. However, the pre-test and post-test difference scores of nutrition selfefficacy of students did not differ significantly. According to these results, it is recommended to give nutrition training to students within a specific program.

\footnotetext{
*Bu çalışmanın bir bölümü, II. Uluslararası Avrasya Sosyal Bilimler Kongresi’nde (ICOESS-2018) sözlü bildiri olarak sunulmuştur.

** Sorumlu Yazar / Corresponding author

e-posta: ozgenelmustafa02@gmail.com
} 


\section{Giriş}

Sağlık, bedenen, zihnen ve sosyal yönden tam bir iyi olma halidir (World Health Organization [WHO], 1948). Sağlığı etkileyen pek çok faktör bulunmaktadır. İnsan sağlığını etkileyen en önemli faktörlerden biri beslenmedir. Beslenme, sağlığ 1 korumak, geliştirmek ve yaşam kalitesini arttırmak için yeterli miktarlarda ve uygun zamanlarda vücudun ihtiyacı olan besinleri almaktır (Applegate, 2011). Ayrica beslenme, bireysel, çevresel, sosyal, kültürel ve ekonomik faktörlerle ilişkili olup, birçok değişkene bağlı bir kavramdır. İnsanlar doğru beslenme davranışları geliştirerek, sağlıklı kalmaya önemli bir katkıda bulunulabilirler. Örneğin günümüzde kanser, kalp-damar, obezite, diş çürümesi ve diyabet gibi hastalıkların beslenme şekli ile ilişki olduğu kanıtlanmıştır (Yabancı ve Pekcan, 2010).

Sağlık Bakanlığı tarafından yapılan Türkiye Beslenme ve Sağlık Araştırması ([TBSA], 2010) verilerine göre 6-18 yaş grubu çocuk ve gençlerde kısa boyluluk görülme sıklığı Türkiye genelinde $\% 6.8$ 'dir. Kısa boy görülme oranı yaşla birlikte artmaktadır. 6-8 yaş grubunda çocukların \%14.9'u kısa boylu iken, $15-18$ yaş grubunda bu oranın \%20.2'ye yükseldiği görülmektedir. Ayrıca yine 6-18 yaş grubu çocuk ve gençlerin \%8.2'si şişman (obez), \%14.3'ü hafif şişman, \%14.9'u zayıf ve \%3.9'u ise çok zayıftır. Sağlık Bakanlığı tarafından yapılan Türkiye Beslenme ve Sağlık Araştırması ([TBSA], 2017) son araştırma sonuçlarına göre obezite kalp-damar, diyabet, tansiyon, solunum ve kanser gibi hastalıklara neden olmaktadır. Dünya Sağlık Örgütü (WHO) obeziteyi en riskli 10 hatalıktan biri olarak kabul ederken, ülkemizde kadınların $\% 20.9$ 'u ve erkeklerin \%13.7'si obezdir. Veriler değerlendirildiğinde Türkiye'de hafif şişmanlık oranının oldukça yüksek olduğu ve gerekli önlemler alınmaması durumunda beden kitle endekslerinin şişmanlık durumuna kaymasının söz konusu olabileceği ifade edilmiştir. Aynı araştırmada zayıflığın da dikkatle izlenmesi gereken bir sorun olduğu, zayıflık oranının hafif şişmanlık düzeyi ile benzer oranlara sahip olduğu belirtilmiştir. $\mathrm{Bu}$ anlamda erken yaşlarda obezite ve kalp-damar hastalıkların önlenmesi önemlidir (Frenn, Malin ve Bansal, 2003). Çocukluk döneminde kazanılan sağlıksız beslenme alışkanlığ 1 , ilerleyen yaşlarda bireyler için pek çok hastalık riski oluşturmaktadır. Okulların, çocuklara beslenme alışkanlıkları veya davranışları kazandırmada en az aile, çevre ve diğer faktörler kadar etkili olduğu söylenebilir. Örneğin, okul yemek hizmetlerinde yapılan çevresel ve fiziksel iyileştirmeler ile sınıf içi ve sınıf dışı çeşitli etkinlikler öğrencilerin beslenme alışkanlıklarını etkilemektedir (Edmundson, Parcel, Feldman, Elder, Perry, Johnson vd., 1996). Çocukların beslenme davranışlarını aileden sonra en çok okul ortamının etkilediği, özellikle ergenlik (adölesan) döneminde okulda verilen beslenme eğitiminin yetişkinlik dönemi beslenme davranışlarını belirlediği bilinmektedir (Branen ve Fletcher, 1999). Çocukluktan erişkinliğe geçiş dönemi olarak bilinen ergenlik dönemi (10-19 yaş), insanın büyümesinin ve gelişiminin hızlandığı önemli bir dönemdir (Pekcan, 2004). Büyüme ve gelişmenin hızlanması, bireyin beslenme ihtiyacını artırır ve değiştirir. Yine bu dönemde alınması gereken kalori, protein, vitamin ve mineral ihtiyacı artış gösterir. Ancak aynı dönemde bireylerin beslenirken genellikle yağlı, tuzlu, şeker oranı yüksek, katkı maddeli, işlenmiş hazır gıdaları daha fazla tercih ettikleri belirtilmektedir (Köseoğlu ve Tayfur, 2017).

Özellikle 2000'li yıllardan sonra insanların yaşam biçimindeki değişiklikler, özellikle yüksek kalorili besin tüketiminin artması, hazır yemek yeme alışkanlığının yaygınlaşması, fiziksel aktivitelerin azaldığı bir çevrenin oluşması çocukların dengeli beslenme, sağlıklı bir yaşam biçimi geliştirme ve devam ettirme olasılığını azaltmıştır (Ahrens, Bammann, De Henauw, Halford, Palou, Pigeot vd., 2006). Bu nedenle okullarda verilecek beslenme eğitimleri, okul kantinlerinde satılacak ve okul menülerinde öğrencilere sunulacak yiyeceklerin niteliği öğrencilerin geliştirecekleri beslenme davranışlarının da temelini oluşturabilir (Güler ve Kubilay, 2004). Bu bağlamda ergenlerin, içinde bulundukları dönem ve okulda geçirdikleri zaman göz önünde bulundurulduğunda okullarda beslenme eğitiminin verilmesinin gerekliliği ortaya çıkmaktadır. Beslenme eğitimlerinin amacı, bireylere doğru bilgilere ulaşmalarını sağlayarak sahip oldukları besinleri, beslenme ilkelerine uygun olarak en iyi şekilde tüketmelerini öğretmektir (Rosenbloom, 2007). Beslenmenin birey ve toplum için önemini fark eden ülkelerde bireyleri obezite ve diyabet gibi hastalıklardan korumak, beslenme alışkanlıklarını ve tercihlerini belirlemek, sağlıklı ve düzenli beslenme davranışı kazandırmak amacıyla çeşitli projeler, çalışmalar veya eğitimler yürütülmektedir (Sormaz, 2013). Örneğin, Amerika Birleşik Devletleri Tarım Bakanlığı ([USDA], 2013), "Ulusal Okul Öğle Yemeği Programı", "Okul Kahvaltı Programı", "Çocuk ve Yetişkin Beslenme Programı", "Yazın Beslenme Programı", "Taze Meyve ve Sebze Programı" ve "Özel Süt Programı" gibi çocuklara sağlıklı yiyecekler sağlayan çeşitli programları yönetmektedir. Bu programların her biri, çocuklara sağlıklı yiyecekler sunmayı, açlık ve şişmanlıkla mücadele etmeyi hedeflemektedir. Benzer şekilde İngiltere'de, İngiliz Beslenme Vakfi (British Nutrition Foundation [BNF], 2018) öğretmenlerin çocukların beslenme alışkanlıklarını şekillendirmede önemli bir rol oynadığına inanmaktadır. $\mathrm{Bu}$ nedenle vakıf, öğretmenlere ücretsiz çevrimiçi eğitim vermektedir. "Food: a fact of life" projesi olarak bilinen bu girişim öğretmenleri beslenme konusunda eğiterek, 3 ile 18 yaş arası çocukları ve gençleri sağlıklı beslenme, yemek pişirme, gıda ve çiftçilik hakkında bilinçlendirmeyi amaçlamaktadır. Eğitimler İngiltere, Kuzey İrlanda, İskoçya ve Galler'deki müfredata uygun bir şekilde hazırlanmış ve bu ülkelerdeki gönüllü öğretmenler tarafından hala sürdürülmektedir. Türkiye'de beslenme eğitimi ile ilgili Milli Eğitim Bakanlığının (MEB) ve Sağlık Bakanlığının (SB) gerçekleştirmiş oldukları birçok proje bulunmaktadır. Çocukların sağlıklı beslenme alışkanlıkları geliştirebilmesi için "Şarkılarla Besleniyorum" (MEB, 2012), "Beslenebilirim" (MEB, 2012), ilköğretim öğrencilerinde beslenme konusunda farkındalık oluşturmak için "Okulumda Besleniyorum" (MEB, 2012), "Yemekte Denge" (MEB, 2012), "İlköğretim Okullarında Beslenme Eğitimi”" (SB, 2012) projeleri gerçekleştirilmiştir. Milli Eğitim Bakanlığı ile Sağlık Bakanlığı arasında imzalan protokol (21.01.2010) ile "Beslenme Dostu Okul Programı Projesi" devam etmektedir. "Beslenme Dostu Okul Programı Projesi" ile okullarda sağlıklı beslenme konusunda bilinçliliğin arttırılması ve bu konuda yapılan iyi uygulamaların desteklenmesi ile okul sağlı̆ıının daha iyi düzeylere çıkarılması hedeflenmiştir. 
Araştırmalar incelendiğinde dünyada birçok ülkede ve ülkemizde yürütülen ulusal düzeyde uygulanmış ve uygulanmaya devam eden pek çok proje bulunduğu, bu projelerin genellikle ülkelerin bazı bakanlıkları ve sivil toplum örgütleri aracılığı ile yürütüldüğü ve öğrencilerin beslenme davranışlarının istenilen düzeyde olmadığı söylenebilir. Yemekhaneleri olmayan okulların bulunması, okul kantinlerinde yapılan iç denetimlerin raporlarının verileri, okullarda doğru beslenme alışkanlıklarının gelişmesi için yeterli ortamların oluşturulamadığının bir göstergesi olarak kabul edilebilir (MEB, 2010). Literatürde beslenme eğitimi uygulamalarının genellikle okul öncesi dönem için yapıldığı, ergenlik dönemine ait çalışmaların sınırlı olduğu fark edilmiştir. Tespit edilen bu durumlar göz önünde bulundurulduğunda, ortaokula devam etmekte olan öğrencilere Deneysel Ölçüme Dayalı Beslenme Eğitimi verilmesinin önemi ortaya çıkmaktadır. Beslenme eğitiminin, ergenlik dönemindeki öğrencilerin yedikleri yiyecek türlerini ve içtikleri su miktarlarını, günlük beslenme davranışlarını olumlu yönde değiştireceği, erken yaşlarda okulda kazandıkları beslenme davranışlarını ve öz-yeterliklerini geliştireceği ve bu çalışmanın alana katkı sağlayacağ beklenmektedir. $\mathrm{Bu}$ bağlamda araştırmanın amacı, araştırmacılar tarafından geliştirilen "Deneysel Ölçüme Dayalı Beslenme Eğitimi, ortaokul öğrencilerinin beslenme davranışlarını ve beslenme öz-yeterliklerini olumlu etkiler." temel hipotezini test etmektir. Araştırmanın temel hipotezi doğrultusunda aşağıdaki alternatif hipotezler test edilmiştir.

$\mathrm{H}_{1-1}$ Deneysel Ölçüme Dayalı Beslenme Eğitimi, öğrencilerin beslenme öz-yeterlik düzeylerini olumlu yönde etkiler.

$\mathrm{H}_{1-2}$ Deneysel Ölçüme Dayalı Beslenme Eğitimi, öğrencilerin beslenme davranışlarını olumlu yönde etkiler.

\section{Yöntem}

$\mathrm{Bu}$ bölümde araştırma modeline, deneysel işlem sürecine, çalışma grubuna, veri toplama araçlarına ve verilerin analizine yer verilmiştir.

\subsection{Araștırma Modeli}

Araştırmada, nicel araştırma modellerinden, kontrol gruplu ön test-son test deneysel desen kullanılmıştır. Kontrol gruplu ön test-son test deneysel desende gruplardaki katılımcilar gruplara yansız-seçkisiz yolla atanır. Ön test yapılarak grupların bağımsız değişkenden aldıkları puanlar karşılaştırılır. Sonraki aşamada deneysel işlem yapılır ve grupların bağımsız değişkenden aldıkları son test puanları tekrar karşılaştırılır (Gliner, Morgan, \& Leech, 2015).
Tablo 1. Kontrol gruplu ön test-son test deneysel desen

\begin{tabular}{|c|c|c|c|}
\hline Gruplar & Ön Test & $\begin{array}{l}\text { Deneysel } \\
\text { İşlem }\end{array}$ & Son Test \\
\hline Deney & $\begin{array}{l}\text { Beslenme } \\
\text { Öz-yeterlik } \\
\text { Ölçeği ve } \\
\text { Beslenme } \\
\text { Davranış } \\
\text { Ölçeği }\end{array}$ & $\begin{array}{l}\text { Deneysel } \\
\text { Ölçüme } \\
\text { Dayalı } \\
\text { Beslenme } \\
\text { Eğitimi }\end{array}$ & $\begin{array}{l}\text { Beslenme } \\
\text { Öz-yeterlik } \\
\text { Ölçeği ve } \\
\text { Beslenme } \\
\text { Davranış } \\
\text { Ölçeği }\end{array}$ \\
\hline Kontrol & $\begin{array}{l}\text { Beslenme Öz- } \\
\text { yeterlik Ölçeği } \\
\text { ve Beslenme } \\
\text { Davranış } \\
\text { Ölçeği }\end{array}$ & --------- & $\begin{array}{l}\text { Beslenme } \\
\text { Öz-yeterlik } \\
\text { Ölçeği ve } \\
\text { Beslenme } \\
\text { Davranış } \\
\text { Ölçeği }\end{array}$ \\
\hline
\end{tabular}

Tablo 1 incelendiğinde kontrol grubuna herhangi bir beslenme eğitimi verilmediği, deney grubuna Deneysel Ölçüme Dayalı Beslenme Eğitiminin verildiği görülmektedir. Öğrencilerin deney öncesi ve deney sonrası beslenme öz-yeterliklerini ve beslenme alışkanlıklarını belirlemek için iki ölçek kullanılmıştır. Deneysel ölçüme dayalı beslenme eğitiminde öğrencilerin; doğru ve yeterli beslenme hakkında bilgilere ulaşmaları sağlanmıştır. Eğitim görsel materyaller, kısa filmler, örnek beslenme uygulamaları ve çeşitli deneylerle desteklenmiştir.

\section{2. Çalışma Grubu}

Araştırma 2017-2018 Eğitim-Öğretim yılında İstanbul ili, Ümraniye ilçesinde aynı okulda öğrenim gören 7. Sınıf öğrencileri ile yürütülmüştür. Katılımcılar gruplara seçkisiz yolla atanmıştır. Gruplar, seçkisiz olarak 19'u kontrol, 19'u deney olmak üzere 38 gönüllü öğrenciden oluşmuştur. 38 öğrencinin 19’u erkek ve 19'u kız öğrencidir.

\subsection{Veri Toplama Araçları}

$\mathrm{Bu}$ araştırmada, Amerika'da bir araştırma projesi olan CATCH (Child and Adolescent Trial for Cardiovascular Health) kapsamında çocukların ve gençlerin kalp sağlığını korumayı, iyileştirmeyi ve kardiyovasküler hastalık risklerini azaltmayı sağlamak için geliştirilen ve Öztürk (2010) tarafından Türkçeye uyarlanan Çocukların Beslenme Özyeterliği ve Beslenme Davranış Ölçekleri kullanılmıştır. Bu ölçeklerden ilki, Çocuk Beslenme Öz-yeterlik Ölçeğidir (ÇBÖÖ). Bu ölçek, çocukların kalp sağlığını geliştirici besinleri (az yağlı ve az tuzlu) yemelerini sağlayan öz-yeterliği ölçmektedir. Çocuk Beslenme Öz-yeterlik Ölçeği, çocukların yiyecek seçimlerinin açıklanmasını kolaylaştıran bir ölçektir. Ölçek, çocukların sağlıklı yiyecekleri tercih edip etmeyeceklerini ölçmeyi amaçlayan 15 maddelik ve 3 'lü likert tipi bir ölçektir ("-1=emin değilim", “ $0=$ biraz eminin", " $+1=$ çok eminim). Ölçekten -15 ile +15 arasında puan alınabilmektedir. Ölçekten alınan yüksek puan beslenme özyeterliğinin yüksek olduğunu ve daha sağlıklı yiyecekler tercih edildiğini göstermektedir. 
Araştırmada kullanılan ikinci ölçek ise Beslenme Davranış Ölçeğidir (BDÖ). Ölçek, çocukların hangi tür besinleri tükettiklerini (az yağlı/ tuzlu veya çok yağlı/tuzlu) tespit edebilmek için bazı besin gruplarının ve seçeneklerinin sunulduğu 14 sorudan oluşan ve sik tüketilen yiyeceklerin görsellerinin kullanıldığı bir ölçektir. Çocuklara karşılaştırılabilir besinler gösterilerek iki besin arasından hangisini daha çok (sık) tercih ettiği sorulmaktadır. Ölçekte sağlıksız besinler için -1 ve sağlıklı besinler için +1 puan verilmekte ve toplam -14 ile +14 aralığında puan alınmaktadır. Ölçekten alınan toplam puanın yüksekliği bireyin sağlıklı beslenme alışkanlığını göstergesi olarak kabul edilmektedir (Parcel, Edmundson, Perry, Feldman, O'Hara-Tompkins, Nader vd., 1995).

\subsection{Verilerin toplanmas1}

Çalışmanın yürütüleceği deney ve kontrol grupları ile veri toplama araçları belirlendikten sonra veriler araştırmacılar tarafından toplanmıştır. Katılımcılara ölçekleri nasıl dolduracakları ile ilgili gerekli açıklamalar yapılmış ve zaman sınırlaması getirilmemiştir. Katılımcılara araştırmadan istedikleri zaman çıkabilecekleri hatırlatılmıştır. Deneysel işlem ve ölçeklerin uygulaması için İstanbul İl Milli Eğitim Müdürlüğü'nden ve öğrenci velilerinden gerekli izinler alınmıştır.

\subsection{Verilerin Analizi}

Deneysel işlem öncesi ve sonrası kontrol ve deney gruplarının beslenme öz-yeterlik düzeyleri ve beslenme alışkanlıklarını belirlemek için Beslenme Öz-yeterlik Ölçeği ve Beslenme Davranış Ölçeği ile ön test ve son test yapılmıştır. Grupların, beslenme öz-yeterlik düzeyleri ve beslenme davranışları, bağımlı değişkenine ait ölçümlerin karşılaştırılması için ilişkisiz/bağımsız gruplar $\mathrm{t}$ testi (Independent Samples TTesti) analizi yapılmıştır. İlişkisiz-bağımsız gruplar t-testi deney ve kontrol gruplarından ölçüm sonucu elde edilen puan farklarının istatistiksel olarak anlamlı olup olmadığını test etmek için kullanılmaktadır (Büyüköztürk, 2012: 39). Grupların öntest ve sontest puanlarına ait betimsel değerler Tablo 2 ve Tablo 3 'te verilmiştir.

Tablo 2. Ölçeklerin öntest puanlarına ait betimsel değerler

\begin{tabular}{lcc}
\hline N & $\begin{array}{c}\text { Beslenme Öz- } \\
\text { yeterlik }\end{array}$ & $\begin{array}{c}\text { Beslenme } \\
\text { Davranışları }\end{array}$ \\
\hline Ortalama (mean) & 38 & 38 \\
Ortanca (medyan) & 5.657 & 1.842 \\
\cline { 2 - 3 } Tepe değer (mode) & 6.50 & 2.00 \\
Standart sapma (Ss) & 3.00 & 4.00 \\
Varyans & 5.672 & 4.863 \\
Ranj & 32.177 & 23.650 \\
En küçük puan & 23.00 & 26.00 \\
En yüksek puan & -8.00 & -12.00 \\
Çarpıklık (skewness) & 15.00 & 14.00 \\
Basıklık (kurtosis) & -.434 & -.165 \\
\hline
\end{tabular}

Tablo 3. Ölçeklerin sontest puanlarına ait betimsel değerler

\begin{tabular}{lrr}
\hline & $\begin{array}{c}\text { Beslenme Öz- } \\
\text { yeterlik }\end{array}$ & $\begin{array}{c}\text { Beslenme } \\
\text { Davranışları }\end{array}$ \\
\hline N & 38 & 38 \\
Ortalama (mean) & 7.263 & 3.026 \\
Ortanca (medyan) & 9.00 & 4.00 \\
Tepe değer (mode) & 12.00 & 6.00 \\
Standart sapma & 5.320 & 5.010 \\
Varyans (variance) & 28.307 & 25.107 \\
Ranj (range) & 18.00 & 22.00 \\
En küçük puan & -3.00 & -8.00 \\
En yüksek puan & 15.00 & 14.00 \\
Çarpıklık (skewness) & -.544 & -.007 \\
Basıklık (kurtosis) & -.936 & .125 \\
\hline
\end{tabular}

Tablo 2 ve Tablo 3 incelendiğinde beslenme öz-yeterlik ve beslenme davranışları ölçeklerinden elde edilen ön test ve son test puanlarının araştırmanın amacına uygun analizlerin yapılmasına elverişli olduğu görülmektedir.

\subsection{Deneysel İşlem}

Ergenlik çağında bulunan çocukların fiziksel, bilişsel ve sosyal gelişimlerinin yanında büyüme ve olgunlaşmanın hızlanması, bireyin beslenme ihtiyacının farklılaşmasına neden olmaktadır. Ergenler için düzensiz öğün ve öğün aralarında atıştırma, ev dışında yemek yeme alışkanlığı ve hazır beslenme (fast-food) biçimi, bu dönemdeki beslenme alışkanlıklarının yaygın olarak görülen özelliklerindendir (Demirsezen ve Coşansu 2005). Bu bağlamda, Deneysel Ölçüme Dayalı Beslenme Eğitimi, ergenlik çağında bulunan öğrencilerin gelişim dönemi özelliklerine uygun bir şekilde tasarlanmış, dikkat çekme ve doğru bilgiye öğrencinin kendisinin ulaşmasını sağlayacak bir eğitim programı olarak planlanmıştır. Deneysel Ölçüme Dayalı Beslenme Eğitimi, aktif öğrenme ve proje tabanlı öğrenme modellerinden ve yapılandırmacı anlayıştan yararlanılarak geliştirilmiştir. Aktif öğrenme, bireyin öğrenme sorumluluğunu üstlendiği, öğretmenin rehberlik ettiği, okuma, dinleme, izleme, arama, düşünme, anlama, yazma ve konuşma gibi öğrenme faaliyetlerine dayalı olarak bireyin deneyimlerine dayanır (Jayawardana, Hewagamage ve Hirakawa, 2001; Mattson, 2005). Proje tabanlı öğrenme, öğrencilerin anlamlı öğrenmelerini ve problem çözme becerilerini kapsayan, öğrencilerin bilgilerini yapılandırmaları için kendi kendilerine çalışmalarına ve kendi ürünlerini ortaya koymalarını sağlayan eğitim ve öğretim modelidir (Saracaloğlu, Özyılmaz Akamca ve Yeşildere, 2006). Yapılandırmacı yaklaşım ise öğrenmenin bilişsel ve sosyal süreçler aracılığı ile birey tarafından gerçekleştirildiğini savunmaktadır (Arslan, 2007). Araştırmanın amacı doğrultusunda öğrencilerin öğrenme sürecinin merkezinde olmasına özen gösterilmiş, verilen eğitimde etkinliklerin ve deneylerin öğrenciler tarafından yapılması sağlanmıştır.

Deneysel Ölçüme Dayalı Beslenme Eğitiminin 8 temel hedefi bulunmaktadır. Bunlar (i) Besin grupları ve besinlerin vücuttaki görevlerini öğrenebilme, (ii) yaş gruplarına göre 
beslenme ihtiyaçlarını bilme, (iii) doğru beslenme alışkanlıklarını öğrenebilme, (iv) yiyeceklerin etiketlerini okuyabilme, $(v)$ şeker-yağ-tuz gibi yiyecek gruplarını doğru ve yeterli miktarda tüketebilme, (vi) yeteri kadar su tüketebilme, (vii) içinde bulunulan koşulları değerlendirilerek, kişiye özel beslenme stratejisi geliştirebilme, (viii) beden kitle endeksini (BKİ) belirleyebilmedir (Karaağaoğlu, 2007).

Belirtilen hedefler doğrultusunda öğrencilerin içinde bulundukları gelişim dönemini de göz önünde bulundurarak, kendi sağlık durumlarını gözden geçirmeleri, beslenme şekillerini değerlendirmelerini sağlayacak, belirli aşamalarında çeşitli deneysel çalışmaları içeren bu eğitim, Deneysel Ölçüme Dayalı Beslenme Eğitimi şeklinde ifade edilmiştir. Deneysel Ölçüme Dayalı Beslenme Eğitiminde bilgi doğrudan verilmemiş, deneysel ölçümlerle öğrencilerin dikkatleri çekilmiş, kendi doğru beslenme şekillerini kendilerinin araştırmaları beklenmiştir. Bu konuda öğrencilere yalnızca rehberlik yapılmış, doğru bilgiye ulaşmaları konusunda yardımcı olunmuştur. Tüm bu veriler doğrultusunda araştırmacılar tarafından geliştirilen Deneysel Ölçüme Dayalı Beslenme Eğitimi Ümraniye'de bir imam hatip ortaokulunda yapılmış, deney grubundaki öğrencilere 4 haftalık bir sürede haftalık 4'er saat olmak üzere toplam 16 saat eğitim verilerek tamamlanmıştır.

Birinci hafta: Deney ve kontrol gruplarına ön testler uygulanmıştır. MEB ve Sağlık Bakanlıklarının programları, işbirliği protokolleri incelenerek hazırlanan eğitim programı hakkında öğrenciler bilgilendirilmiştir. Öğrencilerin beslenmenin tanımı, önemi, sağlıklı ve sürdürülebilir beslenme ile ilgili konularda dikkatleri çekilmiş, onları araştırmaya sevk edecek filmler, beslenme teorileri ve bireylerin beslenme tercihleri gibi konuları içeren araştırmaların sonuçları paylaşılmıştır. Ailelerle iletişime geçilmiş, Sağlık Bakanlığı'nın paylaştığı broşürler velilere dağıtılmıştır.

Ikkinci hafta: Paketlenmiş hazır besinlerin insan sağlı̆̆ına etkilerini gösteren deneyler yapılmıştır. Öğrencilerin okula getirdikleri bisküvi, çikolata, cips vb. yiyeceklerin içindekiler bölümünün doğru bir şekilde okunması sağlanmıştır. Kısaltılmış isimlerle içindekiler bölümüne yazılan katkı maddelerinin insan sağlığına olan zararları tartışılmıştır.

Üçüncü hafta: Örnek bir öğle yemeği uygulaması gerçekleştirilmiş, "Hangi besini neden tüketirim?" konulu poster çalışması yapılmıştır. Öğrencileri hazır beslenme alışkanlıklarına iten faktörler tartışılmıştır. Öğrencilerden evde ailelerinden destek alarak sağlıklı atıştırmalıkların nasıl yapılabileceğini araştırmaları, kendi yemek tariflerini bularak videolarını çekmeleri istenmiştir. Beden Kitle İndeksi (BKI) hesaplaması ve sağlıkla ilişkisi tartışılmıştır. Sınıfta gönüllü öğrencilerin BKI'leri hesaplanmıştır.

Dördüncü hafta: Öğrencilerin hazırladığı video çalışmalarını sınıfta sunmaları istenmiştir. Örnek yemek tariflerinin videoları izletilmiştir. Farklı ülkelerde yaşayan insanların beslenme davranışları ve hastalık oranları ile ilgili araştırma sonuçları tartışılmıştır. Sağlık bakımından uygun bir akşam yemeğinde bulunması gereken yiyeceklerden örnekler verilmiştir. Medyanın çocukların beslenme davranışlarını nasıl etkilediği konusu örneklerle tartışılmıştır. Deney ve kontrol gruplarına son test uygulamaları yapılmıştır.

\section{Bulgular ve Yorumlar}

Araştırmanın genel amacı doğrultusunda iki alternatif hipotez ileri sürülmüştür. $\mathrm{H}_{1-1}$ : “Deneysel Ölçüme Dayalı Beslenme Ĕ̈itimi öğrencilerin beslenme öz-yeterliklerini olumlu yönde etkiler." hipotezini test etmek için deney ve kontrol gruplarının beslenme öz-yeterlik ölçeğinden elde edilen ön test puanları karşılaştırılmıştır. Deney ve kontrol gruplarına ait ön test puanları arasında anlamlı farklılık olup olmadığını belirlemek amacıyla yapılan ilişkisiz gruplar t testi sonuçları Tablo 4'te verilmiştir.

Tablo 4. Beslenme Öz-yeterlik Ölçeği Öntest Puanları İlişkisiz Gruplar t Testi Sonuçları

\begin{tabular}{lccccccc}
\hline Grup & Ölçüm & $\mathbf{N}$ & $\mathbf{X}$ & Ss & Sd & t & p \\
\hline Deney & \multirow{2}{*}{ Öntest } & 19 & 5.789 & 5.987 & \multirow{2}{*}{36} & \multirow{2}{*}{141} & \multirow{2}{*}{.889} \\
Kontrol & & 19 & 5.526 & 5.501 & & & \\
\hline
\end{tabular}

Tablo 4 incelendiğinde deney ve kontrol grubundaki öğrencilerin beslenme öz-yeterlik ön test puanları arasında anlamlı bir farklılı̆̆ın olmadığ 1 görülmektedir $\left(\mathrm{t}_{[36]}=.889\right.$; p>.05). Başka bir ifadeyle deney ve kontrol gruplarının beslenme öz-yeterlik ön test puanları birbirine benzerdir. Deneysel işlem öncesi elde edilen bu bulgu (deney ve kontrol grupların bağımlı değişken açısından benzer olması) deneysel araştırmalarda istenen bir durumdur. Yapılan deneysel işlemin etkili olup olmadığını belirlemek için grupların son test puanlarından ön test puanları çıkarılmış, elde edilen bu farkın anlamlı olup olmadığını tespit etmek için yapılan ilişkisiz gruplar t testi sonuçlar Tablo 5'de verilmiştir.

Tablo 5. Beslenme Öz-yeterlik Ölçeği Öntest ve Sontest Fark Puanları Arasındaki İlișkisiz Gruplar t Testi Sonuçları

\begin{tabular}{llcccccc}
\hline Grup & Ölçüm & $\mathbf{N}$ & $\mathbf{X}$ & Ss & Sd & t & p \\
\hline Deney & Fark & 19 & 2.579 & 3.237 & \multirow{2}{*}{36} & \multirow{2}{*}{1.928} & .062 \\
Kontrol & puanları & 19 & 0.632 & 2.985 & & & \\
\hline
\end{tabular}

Tablo 5 incelendiğinde deney ve kontrol grubundaki öğrencilerin beslenme öz-yeterlik son test ve ön test fark puanları arasında anlamlı bir farklılığın olmadığı görülmektedir $\left(\mathrm{t}_{[36]}=1.92 ; \mathrm{p}>.05\right)$. Ancak grupların fark puanları incelendiğinde deney grubundaki öğrencilerin beslenme öz yeterliği fark puanlarının $(X=2.57)$ kontrol grubundaki öğrencilerin fark puanlarından $(X=0.63)$ daha yüksek olduğu görülmektedir. Başka bir ifadeyle deney grubundaki öğrencilerin, kontrol grubundaki öğrencilere göre daha sağlıklı yiyecekler tercih ettikleri söylenebilir.

\footnotetext{
$\mathrm{H}_{1-2}$ : "Deneysel Ölçüme Dayalı Beslenme Ĕ̆itimi öğrencilerin beslenme davranışlarını olumlu yönde etkiler.” hipotezini test etmek için deney ve kontrol gruplarının beslenme davranış ölçeğinden elde edilen ön test puanları karşılaştırılmıştır. Deney ve kontrol gruplarına ait ön test puanları arasında anlamlı farklılık olup olmadığını belirlemek amacıyla yapılan ilişkisiz gruplar t testi sonuçları Tablo 6'da verilmiştir.
} 
Tablo 6. Beslenme Davranış Ölçeği Ön test Puanları İlişkisiz Örneklemler t Testi Sonuçları

\begin{tabular}{lccccccc}
\hline Grup & Ölçüm & $\mathbf{N}$ & $\mathbf{X}$ & $\mathbf{S s}$ & $\mathbf{S d}$ & $\mathbf{t}$ & $\mathbf{p}$ \\
\hline Deney & \multirow{2}{*}{ Öntest } & 19 & 1.684 & 6.119 & \multirow{2}{*}{36} & .198 & .845 \\
Kontrol & & 19 & 2.000 & 3.333 & & & \\
\hline
\end{tabular}

Tablo 6 incelendiğinde deney ve kontrol grubundaki öğrencilerin beslenme davranış ön test puanları arasında anlamlı bir farklılığın olmadığ 1 görülmektedir $\left(\mathrm{t}_{[36]}=.845\right.$; p>.05). Başka bir ifadeyle deney ve kontrol gruplarının beslenme davranışları ön test puanları birbirine benzerdir. Deneysel işlem öncesi elde edilen bu bulgu (deney ve kontrol grupların bağımlı değişken açısından benzer olması) deneysel araştırmalarda istenen bir durumdur. Yapılan deneysel işlemin etkili olup olmadığını belirlemek için grupların son test puanlarından ön test puanları çıkarılmış, elde edilen bu farkın anlamlı olup olmadığını tespit etmek için yapılan ilişkisiz gruplar t testi sonuçlar Tablo 7'de verilmiştir.

Tablo 7. Beslenme Davranış Ölçeği Ön test ve Son test Fark Puanları İlişkisiz Örneklemler t Testi Sonuçları

\begin{tabular}{llcccccc}
\hline Grup & Ölçüm & $\mathbf{N}$ & $\mathbf{X}$ & Ss & Sd & t & p \\
\hline Deney & Fark & 19 & 3.368 & 5.500 & \multirow{2}{*}{36} & 2.465 & .019 \\
Kontrol & puanları & 19 & -1.000 & 5.426 & & & \\
\hline
\end{tabular}

Tablo 7 incelendiğinde grupların son test ile ön test puanları arasındaki fark puanları anlamlı farklılık göstermektedir $\left(\mathrm{t}_{[36]}=2.46 ; \mathrm{p}<.05\right)$. Deney grubundaki öğrencilerin beslenme davranış fark puanları $(X=3.36)$, kontrol grubundaki öğrencilerin fark puanlarından $(X=-1.00)$ daha yüksektir. $\mathrm{Bu}$ bulgu, deney grubuna verilen deneysel ölçüme dayalı beslenme eğitiminin öğrencilerin beslenme davranışlarını anlamlı bir şekilde ve olumlu yönde etkilediğini göstermektedir. Deneysel araştırmalarda grupların son test puanlarından ön test puanları çıkarılarak elde edilen fark puanlarının anlamlı farklılık göstermesi yeterli değildir. Bu anlamlı farklılığın etki büyüklüğü de hesaplanmalıdır. Etki büyüklüğünü hesaplamak için Eta-kare ve Cohen d formüllerinden yararlanılmıştır. Verilen eğitimin etki büyüklüğü Eta-kare $\left(\eta^{2}\right) \quad 0.14$ olarak hesaplanmıştır $\left(\eta^{2}=t^{2} /\left[t^{2}+\left(n_{1}+n_{2}-2\right)\right]\right)$. Eta-kare etki büyüklüğü değerine göre deney grubundaki öğrencilerin beslenme davranışları puanlarındaki gözlenen varyansın \%14'ünü Ölçüme Dayalı Beslenme Eğitimine bağlı olduğu söylenebilir. Çalışmada Cohen etki büyüklüğü ise $\mathrm{d}=.43$ olarak hesaplanmıştır $\left(\mathrm{d}=\mathrm{X}_{1}-\right.$ $\left.\mathrm{X}_{2} / \mathrm{Sd}_{\text {pooled}}\right)$. Başka bir ifadeyle deneysel ölçüme dayalı beslenme eğitimi öğrencilerin beslenme davranışlarına orta düzeyde etki etmiştir.

\section{Sonuç, Tartışma ve Öneriler}

$\mathrm{Bu}$ çalışmanın amacı, ergenlik dönemdeki ortaokul öğrencilerinin gelişim dönemi özellikleri göz önünde bulundurularak hazırlanan Deneysel Ölçüme Dayalı Beslenme Eğitimi'nin öğrencilerin beslenme davranışlarına ve beslenme öz-yeterliklerine etkisinin olup olmadığı belirlemektir. Araştırmanın amacı doğrultusunda belirlenen hipotezleri test etmek için 38 öğrenci ile gerçekleştirilen kontrol gruplu ön test-son test deneysel desen uygulanmıştır. Deneysel işleme başlamadan önce deney ve kontrol gruplarının beslenme davranışlarının ve beslenme öz-yeterliklerinin ön test puanları karşılaştırılmış ve grupların puanlarının birbirinden anlamlı farklılık göstermediği belirlenmiştir. Daha sonra 4 haftalık ve 16 saatlik deney grubuna deneysel ölçüme dayalı beslenme eğitimi verilmiş, kontrol grubuna herhangi bir eğitim verilmemiştir. Eğitim tamamlandıktan sonra deney ve kontrol gruplarına beslenme davranış ölçeği ve beslenme öz-yeterlik ölçeği tekrar uygulanarak son test puanları elde edilmiştir. Yapılan bağımsız gruplar $\mathrm{t}$ testi sonucuna göre deney ve kontrol grubundaki öğrencilerin beslenme öz-yeterlik ön test ve son test fark puanları arasında anlamlı bir farklılık tespit edilmemiştir. Başka bir ifadeyle Deneysel Ölçüme Dayalı Beslenme Eğitiminin, deney grubundaki öğrencilerin beslenme öz-yeterliklerini etkilemediği görülmüştür. $\mathrm{Bu}$ bulguya göre "Deneysel Ölçüme Dayalı Beslenme Eğitiminin, öğrencilerin beslenme öz-yeterlik düzeylerini olumlu etkiler. $\left(\mathrm{H}_{1-1}\right)$ " hipotezi reddedilmiştir. Bununla birlikte deney grubundaki öğrencilerin beslenme öz-yeterlik fark puanlarının kontrol grubundaki öğrencilerin beslenme öz-yeterlik fark puanlarından daha yüksek olduğu belirlenmiştir. Araştırmadan elde edilen bu bulgunun aksine Frenn, Malin ve Bansal (2003) tarafından yapılan araştırmada ortaokul öğrencilerine diyet yağları kontrol edilerek ve fiziksel aktiviteleri artırılarak uygulanan eğitim, öğrencilerin öz-yeterliklerini etkilemiştir. Düşük öz-yeterlik algısı ile yüksek yağlı gıdaların tüketimi ilişkili bulunmuştur. Bununla birlikte beşinci sınıf öğrencilerinin beslenme davranışlarını etkileyen en önemli unsurun beslenme öz-yeterlikleri olduğu belirlenmiştir (Öztürk, 2010). Araştırmalarda ulaşılan bulguların farklılığının iki nedeni olabilir. Bunlardan birincisi beslenmeyi etkileyen değişkenlerin bazılarının hemen değişmediği, değişse bile hemen fark edilemeyeceği unutulmamalıdır (Öztürk Haney ve Erdoğan, 2013). İkincisi, öz-yeterlik, bireyin davranışlarını ve yaşamını etkileyen faktörleri kontrol altına alma yeteneği ile ilgili inancıdır (Bandura, 1994'den akt., Telef ve Karaca, 2012). Beslenme öz-yeterliği ise bireyin sağlıklı besinler tercih edebileceğine yönelik inancı olarak tanımlanabilir (Abusabha ve Achterberg, 1997). Öğrencilerin beslenme öz-yeterliklerinin, verilen eğitim sonucunda değişmemesi, bireyin beslenmeye yönelik inançlarının dört haftalık gibi bir sürede değişmediği veya değişmeyeceği söylenebilir. Çünkü öz-yeterlik olarak ifade edilen beslenme inançlarının hem kısa sürede oluşmadığ hem de sahip olunan bir inancin kısa sürede değişmeyeceği göz önünde bulundurulmalıdır. Özetle farklılığın temel nedeni olarak ele alınan bağımsız değişkenin doğasından kaynaklandığı söylenebilir.

Araştırmada elde edilen diğer bir bulguya göre deney ve kontrol grubundaki öğrencilerin beslenme davranışlarında, ön test ve son test fark puanları arasında anlamlı bir farklılık tespit edilmiştir. Başka bir ifade ile deney ve kontrol grubundaki öğrencilerin beslenme davranışları arasında anlamlı farklılığın deney grubu lehine olduğu görülmüştür. Deneysel Ölçüme Dayalı Beslenme Eğitiminin, öğrencilerin beslenme davranışlarını olumlu yönde ve orta düzeyde etkilediği tespit edilmiştir. $\mathrm{Bu}$ bulguya göre "Deneysel Ölçüme Dayalı Beslenme Eğitimi, öğrencilerin beslenme davranışlarını olumlu etkiler. $\left(\mathrm{H}_{1-2}\right)$ " hipotezi doğrulanmış ve kabul edilmiştir. Alanda yapılan diğer çalışmalar incelendiğinde, örneğin Yeşilyurt (2017), yaşam temelli öğrenme modeliyle geliştirilen eğitimin deney grubundaki öğrencilere, beslenme farkındalığı kazandırılmasına katkı sağladığını tespit etmiştir. Başka bir araştırmada Kaplan (2011), beslenme eğitiminin, öğrencilerin beslenme alışkanlıklarını olumlu yönde 
değiştirdiği, bilgi düzeylerinin artış gösterdiği ve çalışmada verilen beslenme eğitiminin etkili olduğunu bulmuştur. Goloğlu'nun (2009) yaptığı çalışmada ise sosyo-bilimsel aktivitelerle verilen dengeli beslenme eğitiminin öğrencilerin kavram öğrenmelerini ve öğrencilerin karar verme becerilerinin gelişmesine olumlu etkisi olduğu fark edilmiştir. Obalı (2009) tarafından gerçekleştirilen araştırmada ise okulöncesi altı yaş grubu çocuklara verilen proje tabanlı beslenme eğitiminin, çocukların beslenme bilgi düzeylerini arttırmada geleneksel eğitime göre daha etkili olduğunu belirlemiştir. Sütçü'nün (2006) gerçekleştirdiği deneysel çalışmada drama eğitiminin okul öncesi eğitime devam eden altı yaş grubundaki çocukların beslenme alışkanlıklarına olumlu yönde etki ettiği saptanmıştır. Ünver'in (2004) yaptığ 1 çalışmada, beş-altı yaş okulöncesi dönemi çocukları için besin gruplarına yönelik beslenme eğitimi, deney grubundaki çocukların kontrol grubundaki çocuklara oranla, besin gruplarına ilişkin bilgi düzeyleri ve yemek yeme davranışlarında olumlu yönde gelişmeler olduğu tespit edilmiştir. Story, Lytle, Birnbaum ve Perry (2002) tarafindan yapılan araştırmada verilen beslenme eğitimi sonunda, kontrol grubu öğrencileri ile deney grubundaki öğrenciler kıyaslandığında deney grubundaki öğrencilerin öğle yemeğinde, öğün aralarında ve evde sebze-meyve tüketiminin önemli ölçüde arttığı görülmüştür. Lise kız öğrencilerine yönelik okul temelli obezite önleme programı, kız öğrencilerin beslenme alışkanlıklarını etkilemekle birlikte fiziksel aktivite ve kendilik imajlarını da etkilemektedir (Neumark-Sztainer, Story, Hannan ve Rex, 2003). Bu araştırmada ulaşılan bulgular ile literatürde ulaşılan diğer araştırma bulguları birlikte değerlendirildiğinde belirli bir amaç doğrultusunda hazırlanan farklı beslenme eğitimlerinin öğrencilerin beslenme alışkanlıkları, davranışları ve bilgi düzeyleri üzerinde etkili olduğu ve beslenme eğitimi ile ilgili yapılan araştırma bulgularının bu araştırmadan elde edilen bulguyla tutarlılık gösterdiği söylenebilir. Bu nedenle başta okulöncesi eğitim olmakla birlikte tüm eğitim kademelerinde beslenme eğitiminin önemli olduğu kabul edilmeli ve bu önem öğrencilerin ileri eğitim yaşamlarında göz önünde bulundurulmalıdır.

Araştırma bulgularından hareketle okulların, öğrencilerin sağlıklı beslenme davranışlarını ve öz-yeterliklerini geliştirmeyi ve sürdürmeyi sağlayan kurumlar olmayı hedeflemeleri gerektiği söylenebilir. Okullarda öğrencilerin gelişim dönemleri göz önünde bulundurularak beslenme eğitimi ile bilgilendirme ve farkındalık yaratan yeni proje ve ilgili çalışmalar yapılabilir ve yürütülen diğer faaliyetler desteklenebilir. Çünkü bu projeler ve çalışmalar, büyüme, gelişme ve öğrenmeyi olumlu yönde etkilemesinin yanı sıra, doğru beslenme alışkanlıkları kazandırarak çocukların yetişkinlik döneminde kronik hastalıklara yakalanma riskini de azaltabilir (Yabanc1, 2011). Okullarda, daha küçük gruplardan oluşan, farklı öğrenme tekniklerinin bir arada kullanıldığı ve yaş grupları göz önünde bulundurularak, etkililiği test edilebilen uzun vadede sürdürülebilir ve geliştirilebilir beslenme eğitimleri yapılabilir. Bunun gerçekleşebilmesi için de öncelikle öğretmenlere, beslenme konusunda uzman kişilerin de içinde bulunduğu atölye eğitimleri verilebilir. Ayrıca okulda bulunan kantin ve yemekhanelerdeki besinlerin, öğrencilerin sağlıklı ve dengeli beslenmelerini destekleyecek nitelikte olması için yapılan denetimlerin sürekliliği kararlı bir şekilde devam ettirilebilir. Verilen eğitimlerin çocuk ve ergenlik çağındaki öğrencilerin beslenme davranışlarını ve öz-yeterliklerini etkileme düzeyleri ölçülebilir ve eğitimler düzenlenirken hedef grubun gelişim özellikleri göz önünde bulundurulabilir.

\section{Kaynakça}

AbuSabha, R. \& Achterberg, C. (1997). Review of selfefficacy and locus of control for nutrition-and healthrelated behavior. Journal of the American Dietetic Association, 97(10), 1122-1132.

Ahrens, W., Bammann, K., De Henauw, S., Halford, J., Palou, A., Pigeot, I., ... \& European Consortium of the IDEFICS Project. (2006). Understanding and preventing childhood obesity and related disorders-IDEFICS: A European multilevel epidemiological approach. Nutrition, Metabolism and Cardiovascular Diseases, 16(4), 302-308.

Applegate L. (2011). Beslenme ve diyet (H. Özpınar, Çev. Ed.). İstanbul: İstanbul Tıp Kitapevi.

Arslan, M. (2007). Eğitimde yapılandırmacı yaklaşımlar. Ankara Üniversitesi Eğitim Bilimleri Fakültesi Dergisi, 40(1), 41-61.

Branen, L. \& Fletcher, J. (1999). Comparison of college students current eating habits and recollections of their childhood food practices. Journal of Nutrition Education, 31(6), 304-310.

British Nutrition Foundation [BNF]. (2018). Food a fact of life. (Erişim: 01.09.2018), http://www.foodafactoflife.org.uk/Index.aspx

Büyüköztürk, Ş. (2012). Sosyal bilimler için veri analizi el kitabı. Ankara: Pegem Akademi Yayıncılık.

Demirezen, E. \& Coşansu, G. (2005). Adölesan çağı öğrencilerde beslenme alışkanlıklarının değerlendirilmesi. Sürekli Tıp Ĕ̆itimi Dergisi, 14(8), 174178.

Edmundson, E., Parcel, G. S., Feldman, H. A., Elder, J., Perry, C. L., Johnson, C. C., ... \& Webber, L. (1996). The effects of the Child and Adolescent Trial for Cardiovascular Health upon psychosocial determinants of diet and physical activity behavior. Preventive medicine, 25(4), 442-454.

Frenn, M., Malin, S., \& Bansal, N. K. (2003). Stage-based interventions for low-fat diet with middle school students. Journal of Pediatric Nursing, 18(1), 36-45.

Gliner, J. A., Morgan, G. A., \& Leech, N. L. (2015). Uygulamada araştırma yöntemleri: Desen ve analizi bütünleştiren yaklaşım (Çev. Ed.). Ankara: Nobel Yayıncilık.

Goloğlu, S. (2009). Fen eğitiminde sosyo-bilimsel aktivitelerle karar verme becerilerinin geliştirilmesi: Dengeli beslenme (Yayınlanmamış Yüksek Lisans Tezi). Marmara Üniversitesi, Eğitim Bilimleri Enstitüsü, İstanbul.

Güler, G. \& Kubilay, G. (2004). Bir ilköğretim okulu öğrencilerinin fiziksel bakım sorunlarının belirlenmesi. Cumhuriyet Üniversitesi Tip Fakültesi Dergisi, 26(2), 6065 . 
Jayawardana, C., Hewagamage, K. P., \& Hirakawa, M. (2001). Personalization tools for active learning in digital libraries. MC Journal: The Journal of Academic Media Librarianship, 8(1).

Kaplan, B. (2011). Nevşehir ili Özkonak kasabasında bulunan Cumhuriyet ilköğretim okulu ögrencilerine verilen beslenme ě̆itiminin etkinliğinin incelenmesi (Yayınlanmamış Yüksek Lisans Tezi). Çukurova Üniversitesi, Sağlık Bilimleri Enstitüsü, Adana.

Karaağaoğlu, N. (2007). İlköğretim çocuklarl ve adolesanlarda beslenme ve beslenme programlarının geliştirilmesi. (Erişim, 10.03.2018), https://hsgm.saglik.gov.tr/depo/birimler/sagliklibeslenme-hareketli-hayat-db/dokumanlar/Sunumlar/YasGruplari-ve-Beslenme/Ilkogretim-Cocuklari-veAdolesanlarda-Beslenme.pdf

Köseoğlu, S. Z. A., \& Tayfur, A. Ç. (2017). Adölesan dönemi beslenme ve sorunları (Nutrition and issues in adolescence period). Güncel Pediatri, 15(2), 44-57.

Mattson, K. (2005). Why “Active Learning” can be perilous to the profession. Academe. 91(1), 23-26.

Milli Eğitim Bakanlığı (2010). Okul Kantinleri İç Denetim Raporu. İç Denetim Birimi Başkanlığı, 2010/11. (Erişim: 15.03.2018),

http://www.akeo.org.tr/ckfinder/userfiles/files/M_E_B_\% 20\%E2\%80\%93\%20Okul\%20Kantinleri\%20I\%CC\%87c \%CC\%A7\%20Denetim\%20Raporu.pdf

Milli Eğitim Bakanlığı (2012). Okul sağlı̆̆l. (Erişim: 30.03.2018),

http://okulsagligi.meb.gov.tr/www/icerik_goruntule.php? $\mathrm{KNO}=16$

Neumark-Sztainer, D., Story, M., Hannan, P. J., \& Rex, J. (2003). New Moves: a school-based obesity prevention program for adolescent girls. Preventive medicine, 37(1), 41-51.

Obalı, H. (2009). Okulöncesi ĕgitimi almakta olan altı yaş grubu çocuklarına verilen proje yaklaşımıyla beslenme eğitiminin beslenme bilgi düzeyine etkisi (Yayımlanmamış Doktora Tezi). Selçuk Üniversitesi, Sosyal Bilimleri Enstitüsü, Konya.

Öztürk Haney, M. \& Erdoğan, S. (2013). Sağlık davranışı etkileşim modeli: Çocukların beslenme alışkanlıklarını belirlenmek için bir rehber. Dokuz Eylül Üniversitesi Hemşirelik Fakültesi Elektronik Dergisi, 6(4), 218-223.

Öztürk, M. (2010). Çocukların beslenme alışkanlıklarının sağlık davranışı etkileşim modeline göre incelenmesi (Yayımlanmamış Doktora tezi). İstanbul Üniversitesi, Sağlık Bilimleri Enstitüsü, İstanbul.

Parcel, G. S., Edmundson, E., Perry, C. L., Feldman, H. A., O'Hara-Tompkins, N., Nader, P. R., ... \& Stone, E. J. (1995). Measurement of self-efficacy for diet-related behaviors among elementary school children. Journal of School Health, 65(1), 23-27.

Pekcan, G. (2004). Adölesan döneminde beslenme. Klinik Çocuk Forumu, 4(1), 38- 47.
Rosenbloom, A. L. (2007). Physiology of growth. Annales Nestlé (English ed.), 65(3), 97-108.

Sağlık Bakanlığı (2010). Türkiye beslenme ve săgllk araştırması (TBSA) 2010: Saha uygulaması el kitabı. Sağlık Bakanlığı Yayın, (931).

Sağlık Bakanlığı (2012). Beslenme dostu okullar programı. (Erişim: 13.04.2018), https://hsgm.saglik.gov.tr/tr/okulsagligi/beslenme-dostu-okullarprogram\%C4\%B1.html

Sağlık Bakanlığı (2017). Türkiye beslenme ve să̆llk araştırmast (TBSA) 2017. (Erişim: 14.11.2018), https://balikesirism.saglik.gov.tr/TR,43758/2017-yiliturkiye-beslenme-ve-saglik-arastirmasi.html

Saracaloğlu, A., Özyılmaz Akamca, G., Yeşildere, S. (2006). İlköğretimde proje tabanlı öğrenmenin yeri. Türk Ĕgitim Bilimleri Dergisi, 4(3), 241-260.

Sormaz, Ü. (2013). Okul beslenme eğitimi programları. Mehmet Akif Ersoy Üniversitesi Ĕ̈itim Bilimleri Enstitüsü Dergisi, 2(3), 36-48.

Story, M., Lytle, L., Birnbaum, A. \& Perry, C. (2002). Peerled, school-based nutrition education for young adolescents: feasibility and process evalution of the TEENS study. Journal of School Health, 72 (3), 121127.

Sütçü, Z. (2006). Drama eğitiminin okul öncesi eğitime devam eden altı yaş grubundaki çocukların beslenme alışkanlıklarına etkisinin analizi (Yayınlanmamış Yüksek Lisans Tezi). Selçuk Üniversitesi, Sosyal Bilimler Enstitüsü, Konya.

Telef, B. B. \& Karaca, R. (2012). Çocuklar için öz-yeterlik ölçeği; Geçerlik ve güvenirlik çalıșması. Buca Eğitim Fakültesi Dergisi 32, 169-187.

USDA (2013). New meal pattern requirements and nutrition standards, USDA's national school lunch and school breakfast programs. (Erişim: 16.04.2018), https://www.usda.gov/topics/food-and-nutrition

Ünver, Y. (2004). Beş altı yaş okulöncesi dönemi çocukları için geliştirilecek, besin gruplarına yönelik beslenme eğitimi programlarının, çocukların beslenme bilgisi ve davranışlarına etkisi (Yayımlanmamış Yüksek Lisans Tezi). Selçuk Üniversitesi, Sosyal Bilimler Enstitüsü, Konya.

World Health Organisation [WHO]. (1948). "Designing the road to better health and well-being in Europe" at the 14th European Health Forum Gastein. (Erişim: 13.04.2018), http://www.euro.who.int/_data/assets/pdf_file/0003/152 184/RD_Dastein_speech_wellbeing_07Oct.pdf

Yabanc1, N. \& Pekcan, G. (2010). Adolesanlarda beslenme durumu ile fiziksel aktivite düzeyinin vücut bileşimi ve kemik mineral yoğunluğu üzerine etkisi. Sosyal Politika Çalışmaları Dergisi, 22(22).

Yabancı, N. (2011). Okul sağlığı ve beslenme programları. TAF Preventive Medicine Bulletin, 10(3), 361-368.

Yeşilyurt, D. (2017). Yaşam temelli öğrenme modeli ile ortaokul 5. sınıf öğrencilerine să̆lıklı beslenme 
farkındalığının kazandırılması (Yayımlanmamış Yüksek Lisans Tezi). Kafkas Üniversitesi, Fen Bilimleri Enstitüsü, Kars. 

